\title{
Article
}

\section{Silver Nanoparticles from Annona muricata Peel and Leaf Extracts as a Potential Potent, Biocompatible and Low Cost Antitumor Tool}

\author{
María G. González-Pedroza ${ }^{1}{ }^{10}$, Liliana Argueta-Figueroa ${ }^{2}$, René García-Contreras ${ }^{3}$, Yaiza Jiménez-Martínez ${ }^{4}$,

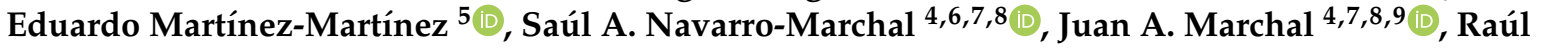 \\ A. Morales-Luckie ${ }^{10, *(1)}$ and Houria Boulaiz ${ }^{4,7,8,9, *(1)}$
}

\section{check for updates}

Citation: González-Pedroza, M.G.;

Argueta-Figueroa, L.;

García-Contreras, R.;

Jiménez-Martínez, Y.;

Martínez-Martínez, E.;

Navarro-Marchal, S.A.; Marchal, J.A.;

Morales-Luckie, R.A.; Boulaiz, H.

Silver Nanoparticles from Annona

muricata Peel and Leaf Extracts as a

Potential Potent, Biocompatible and

Low Cost Antitumor Tool.

Nanomaterials 2021, 11, 1273. https:/

/doi.org/10.3390/nano11051273

Academic Editor: Eleonore Fröhlich

Received: 15 April 2021

Accepted: 6 May 2021

Published: 12 May 2021

Publisher's Note: MDPI stays neutral with regard to jurisdictional claims in published maps and institutional affiliations.
1 Department of Biotechnology, Faculty of Sciences, Autonomous University of the State of Mexico (UAEMex), Toluca 50200, Mexico; mggonzalezp@uaemex.mx

2 Conacyt Chairs, Faculty of Dentistry, Benito Juárez Autonomous University of Oaxaca, Oaxaca 68120, Mexico; 1_argueta_figueroa@hotmail.com

3 Interdisciplinary Research Laboratory, Nanostructures and Biomaterials, National School of Higher Studies (ENES) León Unit, National Autonomous University of Mexico (UNAM), Leon 37684, Mexico; dentist.garcia@gmail.com

4 Regenerative Institute of Biopathology and Medicine (IBIMER), University of Granada, 18016 Granada, Spain; yaijmartinez@hotmail.com (Y.J.-M.); navarrosa@ugr.es (S.A.N.-M.); jmarchal@ugr.es (J.A.M.)

5 Laboratory of Cell Communication and Extracellular Vesicles, National Institute of Genomic Medicine (INMEGEN), Mexico City 14610, Mexico; emartinez@inmegen.gob.mx

6 Department of Applied Physics, Faculty of Sciences, University of Granada, 18071 Granada, Spain

7 Biosanitary Institute of Granada (ibs. GRANADA), SAS-Universidad de Granada, 18016 Granada, Spain

8 Research Unit “Modeling Nature” (MNat), University of Granada, 18016 Granada, Spain

9 Department of Human Anatomy and Embryology, University of Granada, 18016 Granada, Spain

10 Joint Center for Research in Sustainable Chemistry UAEMex-UNAM (CCIQS), Autonomous University of the State of Mexico (UAEMex), Toluca 50200, Mexico

* Correspondence: rmoralesl214@profesor.uaemex.mx (R.A.M.-L.); hboulaiz@ugr.es (H.B.)

\begin{abstract}
Cancer is one of the most prevalent diseases in the world and requires new therapies for its treatment. In this context, the biosynthesis of silver nanoparticles (AgNPs) has been developed to treat different types of tumors. The Annona muricata plant is known for having anticancer activity. Its main compounds present in the leaves, stems and skin, allowing for its use as reducing agents. In this manuscript, AgNPs with leaf extract (AgNPs-LE) and fruit peel extract (AgNPs-PE) of $A$. muricata were biosynthesized obtaining an average nanoparticle diameter sizes smaller than $50 \mathrm{~nm}$, being $19.63 \pm 3.7 \mathrm{~nm}$ and $16.56 \pm 4.1 \mathrm{~nm}$, and with a surface plasmonic resonance (SPR) at 447 and $448 \mathrm{~nm}$, respectively. The lactone functional group present in the LE and PE extracts was identified by the FTIR technique. The behavior and antiproliferation activity of AgNPs-LE and AgNPs-PE were evaluated in breast, colon and melanoma cancer cell lines. Our results showed that Annona muricata fruit peel, which is a waste product, has an antitumor effect more potent than leaf extract. This difference is maintained with AgNPs where the destruction of cancer cells was, for the first time, achieved using concentrations that do not exceed $3 \mu \mathrm{g} / \mathrm{mL}$ with a better therapeutic index in the different tumor strains. In conclusion, we present a low-cost one-step experimental setup to generate AgNPs-PE whose in-vitro biocompatibility and powerful therapeutic effect make it a very attractive tool worth exploiting.
\end{abstract}

Keywords: green synthesis of silver nanoparticles; Annona muricata fruit peel; acetogenins; antiproliferative activity

\section{Introduction}

Cancer is considered a worldwide public health problem [1]. The International Agency for Research on Cancer estimated that in the years 2018 and 2020, 18.1 and 19.3 million 
cancers were diagnosed across the world. However, the COVID-19 pandemic has most probably affected the number of cancer diagnoses in many countries, so the actual number of cancers diagnosed in 2020 will likely have been lower. Global estimates also indicate that the number of new cases will increase over the next two decades to 30.2 million new cases per year by 2040. Currently, colon cancer, breast cancer and melanoma are among the cancers with the highest incidence and mortality rates [2]. Conventional treatments such as chemotherapy, radiotherapy, surgery and hormone therapy have certain limitations [3], and research for new and more efficient therapies is required.

Nowadays, a number of innovative cancer treatments are underway and mostly are in preclinical trials, with challenges remaining in administration, effectiveness and safety. Nanotechnology has led to advanced approaches in the screening, diagnosis, and treatment of cancer [4]. Synthesis of noble metal nanoparticles such as gold, copper and silver for applications in the medical area is of constant interest. In this context, silver nanoparticles (AgNPs) are attractive due to their exclusive optical, electrical, magnetic and thermal properties which can be incorporated into antimicrobial applications, biosensor materials, composite fibers, cryogenic superconducting materials, cosmetic products and electronic components. Moreover, AgNPs have been focused on potential applications in cancer diagnosis and therapy [5]. Generally, the synthesis of AgNPs can be carried out using three different methods, including physical, chemical and biological approaches.

The physical method prepares AgNPs by evaporation-condensation techniques using a tube furnace at atmospheric pressure. It's a speed synthesis process based on the use of radiation as a reducing agent and no hazardous chemical involvement. However, low performance, high energy consumption, solvent contamination, and lack of uniform distribution limit its use [6]. Chemical methods use water or organic solvents in the synthesis of AgNPs [7,8]. They generally employ three main components, such as metal precursors, reducing agents, and stabilizing/protecting agents. Basically, the reduction of silver salts involves two stages: nucleation and growth [9]. It is characterized by its high performance. However, the manufactured particles lack the expected purity, having sedimentation of chemical products on their surfaces. Moreover, it is very difficult to prepare AgNPs with a well-defined size, which requires one more step to prevent particle aggregation. On the other hand, it's an extremely expensive method that causes, during the synthesis process, the formation of too many toxic and dangerous by products [6].

Biological methods overcome these limitations. In fact, currently, production of nanoparticles of defined size using different biological systems including bacteria, fungi, plant extracts and small biomolecules (e.g., vitamins and amino acids) is an alternative method for the synthesis of various nanoparticles such as gold, graphene and AgNPs [10-12]. Green synthesis of AgNPs, based on exploiting the natural capabilities of plant secondary metabolite extract of leaves, roots, stems or, from the shell of a plant to a complete organism, has advantages over routine physical and chemical synthetic approaches. Its one-step experimental setup to reduce and stabilize bulk silver in AgNPs, biocompatible nature, therapeutic importance and low cost make it a very attractive tool worthy of being exploited [13].

In this context, Soursop (Annona muricata), is a plant well known for its anticancer activity [14]. This plant is a species of the genus Annona, of the family Annonaceae, order Magnoliales and division Magnoliophyta [15]. This tree tends to bloom and bear fruit most of the year. It is distributed in the tropical regions of Central and South America, West Africa and Southeast Asia [16], the A. muricata fruit is an edible collective ovoid berry, dark green in colour [17]. The active compounds of A. muricata are acetogenins and polyphenols, among others $[18,19]$, and can be used as reducing agents for the biosynthesis of nanoparticles [20]. It should be noted that the anticancer activity is directly attributed to acetogenins, specifically the lactone functional group. Lactones are an organic compound of the cyclic ester type. This functional group is responsible for blocking the complex I at the mitochondrial level in cancer cells, creating the accumulation of protons through the 
mitochondrial membrane, stopping production of ATP and, therefore, forcing selective apoptosis [21].

At present, several studies have demonstrated the antitumor properties of A. muricata, focusing above all on its leaves as it has been traditionally considered "the cancer killer" in conventional medicine [22-24]. Taking into account that acetogenins predominate in leaves (LE) and peel (PE) of fruit of A. muricata, we used their extracts to synthesize AgNPs-LE and AgNPs-PE to explore and compare their effectiveness and selectivity against different types of tumors.

\section{Materials and Methods}

\subsection{Collection and Conservation of Leaves and Peel of A. muricata}

The leaves and fruits of $A$. muricata were collected in the state of Morelos, in the municipality of Xochitepec $\left(18^{\circ} 46^{\prime} 52^{\prime \prime} \mathrm{N}, 99^{\circ} 12^{\prime} 02^{\prime \prime} \mathrm{W}\right)$, at the beginning of March, being the month in which the botanical maturity of the fruit is reached. The leaves and fruits of A. muricata were characterized in the Herbarium of the Faculty of Sciences, in the UAEMex, State of Mexico, Mexico. Regarding the fruit, it is separated from the peel. Then the leaves and peel of fruit were washed three times with distilled water to remove impurities, and allowed to air dry at room temperature $\left(20^{\circ} \mathrm{C}\right)$ for 15 days.

\subsection{Biosynthesis of Silver Nanoparticles with Extracts of A. muricata}

\subsubsection{Preparation of Aqueous Leaf Extract (LE) and Fruit Peel (PE) from A. muricata}

The leaves and the peel of the fruits were crushed in a mortar until obtaining a homogeneous powder with a size (grain) of $2-3 \mathrm{~mm}$. The extract solutions were prepared by boiling $1 \mathrm{~g}$ of the dry fruit peel in a $100 \mathrm{~mL}$ Erlenmeyer flask of distilled water for ten minutes at $100{ }^{\circ} \mathrm{C}$. The extract was filtered using filter paper (Whatman No. 1) [25]. A second filtration was carried out with tubes of $30 \mathrm{k}$ Amicon Ultra-15 Centrifugal filter devices, at $300 \mathrm{rpm}$ for $10 \mathrm{~min}$. Then, crude extract was obtained via the concentration of extract with the use of reduced pressure. The same process was used to prepare the leaf extract. This extract can be stored at $4{ }^{\circ} \mathrm{C}$ for later use.

\subsubsection{Synthesis of Silver Nanoparticles}

An experimental analysis was carried out, where different tests were performed varying the volume proportions of extracts and silver nitrate $\left(1 \times 10^{-2} \mathrm{M}\right)$ Sigma-Aldrich, ACS reagent, $\geq 99.0 \%$, which were $1: 2,1: 1$ and 2:1; The best concentration was determined by UV-Vis and it was found that, in both cases, the best concentrations were 1:1, consecutively. Subsequently, tubes of $30 \mathrm{k}$ Amicon Ultra-15 Centrifugal filter devices were filtered, at $300 \mathrm{rpm}$ for $10 \mathrm{~min}$, to achieve purification of the generated nanoparticles. The synthesis was carried out as described below. The extract was used for reduction of $\mathrm{Ag}^{+}$ions to $\mathrm{Ag}^{0}$, where $5 \mathrm{~mL}$ of shell extract and leaves were separately added to $5 \mathrm{~mL}$ of aqueous solution of silver nitrate at a concentration of $1 \mathrm{mM}$. The same process was performed to prepare the silver nanoparticles using leaf extract. Silver ions were reduced to metallic silver in $6 \mathrm{~h}$.

\subsection{Characterization}

\subsubsection{Characterization of Optical Properties of AgNPs}

The optical properties of the AgNPs were determined using UV-Vis spectroscopy, with the Varian Cary 5000 double-beam equipment, diluting of the silver nanoparticles in deionized $\mathrm{H}_{2} \mathrm{O}$ until the equipment cell was filled. It was analyzed in a range of 200 to $800 \mathrm{~nm}$, in absorption mode.

\subsubsection{Morphological and Structural Characterization of AgNPs}

The structural properties of the formed nanostructures were characterized, such as morphology, particle size and distribution thereof; for this a JEOL-2100 $200 \mathrm{kV}$ Transmission Electron Microscope (TEM) was used with filament of $\mathrm{LaB}_{6}$. Placing a drop of the AgNPs 
sample on a rack until dry, it was subsequently introduced to the sample holder and assembled in the equipment.

Likewise, a Scanning Electron Microscope (SEM) was used to do a chemical mapping of the main elements present, in addition to performing an EDS analysis to determine and identify them.

\subsubsection{Characterization of the Main Functional Groups Present in the Extracts of Annona muricata and AgNPs}

With the help of the FTIR technique and the Bruker TENSOR 27 model equipment, the main functional groups that are present in the extract were recognized, in addition to justifying the presence of AgNPs. It was achieved by placing a drop on the analysis device and operating in transmittance mode from 600 to $4000 \mathrm{~cm}^{-1}$.

\subsubsection{Characterization of the Zeta Potential}

The hydrodynamic mean diameter of the NC was determined by photon correlation spectroscopy (PCS), using a $4700 \mathrm{C}$ light-scattering device (Malvern Instruments, London, UK) and working with a He-Ne laser $(10 \mathrm{~mW})$. The light scattered by the samples was detected at $173^{\circ}$, and the temperature was set at $25^{\circ} \mathrm{C}$. The diffusion coefficient measured by dynamic light scattering can be used to calculate the size of the AgNPs-LE and AgNPsPE by means of the Stokes-Einstein equation. The homogeneity of the size distribution is expressed as polydispersity index (PDI), which was calculated from the analysis of the intensity autocorrelation function. Electrophoretic mobility $\left(\mu_{\mathrm{e}}\right)$ and $\mathrm{Z}$ potential was measured after diluting a small volume of the (AgNPs-LE and AgNPs-PE) stock (with a total surface equal to $0.05 \mathrm{~m}^{2}$ ) in $1 \mathrm{~mL}$ of the desired buffered solution. It should be noted that all the buffers used in the $\mu_{\mathrm{e}}$ studies had identical ionic strengths, being equal to $0.002 \mathrm{M}$. The $\mu_{\mathrm{e}}$ measurements were made in triplicate using a nano zeta dynamic light-scattering analyzer (Zeta-Sizer Nano Z, Malvern Instruments, UK).

\subsection{Cell Viability Assay}

\subsubsection{Cell Lines and Cytotoxicity Assays}

Breast cancer (MCF-7, MDA-MB-468), colon cancer (HCT-116), Melanoma (A-375) and macrophage cell lines come from the Biobank (Sistema Sanitario Publico Andaluz, Granada, Spain). Cells were grown in Dulbecco's Modified Eagle's Medium (DMEM) (Sigma, St. Louis, MO, USA) supplemented with 10\% fetal bovine serum (FBS) and 1\% penicillin/streptomycin (P/S) (Sigma, St. Louis, MO, USA). The cells $\left(5 \times 10^{3}\right.$ cells) were incubated in 96 -well plates at $37^{\circ} \mathrm{C}$ in a $5 \% \mathrm{CO}_{2}$ atmosphere and were treated with different concentrations of biosynthesized nanoparticles AgNPs-PE and AgNPs-LE (100, 50, 25, 12.5, $6.25,3125,1556 \mu \mathrm{g} / \mathrm{mL})$ and different concentrations of extracts PE and LE $(2000,1750$, $1500,1250,1000,750,500,250 \mu \mathrm{g}$ for 3 days. Then, the medium was removed and $100 \mu \mathrm{L}$ of 3-(4,5-dimethyl-2-thiazolyl)-2, 5-diphenyl-2-tetrazoyl bromide (MTT) (at a concentration of $0.2 \mathrm{mg} / \mathrm{mL}$ ) was added to each well and incubated for three hours. Subsequently, the MTT reagent was removed, and the formazan crystals formed were dissolved in $100 \mu \mathrm{L}$ of dimethyl sulfoxide (DMSO) and analyzed at $570 \mathrm{~nm}$ in a multi-well ELISA plate reader. The inhibitory concentration $50\left(\mathrm{IC}_{50}\right)$ was calculated with the GraphPad Prism program (GraphPad 6 Software San Diego, CA, USA). All of the experiments were plated in triplicate and were carried out at least twice. In addition, non-treated cells were used as controls.

\subsubsection{Morphological Findings}

Morphological findings were assessed using SEM. The cells were grown on sterile coverslips, induced for 6 days with the $\mathrm{IC}_{50}$ concentration of the extracts (PE and LE) and nanoparticles (AgNPs-PE and AgNPs-LE), and treated as described by Cáceres et al., 2019 [26]. A Hitachi S-800 scanning electron microscope (Hitachi, Tokyo, Japan) was used for observations. Counting the number of pores per cell was performed using ImageJ 
with quantification for each cell type from 8 random photos from three independent sample preparations.

\subsubsection{Statistical Analysis}

The collection of the data from the different biological studies represents the mean \pm standard deviation. Two-tailed Student $t$-test was used to compare differences between two groups. A two-tailed $p$-values $<0.05$ was considered statistically significant.

\section{Results and Discussion}

\subsection{Synthesis of Silver Nanoparticles (AgNPs)}

In the context of the generation of nanoparticles and as part of a bottom-up method, different variables for the formation of AgNPs must be recognized such as: temperature, reaction time, concentration of extracts and precursors of metal ions such as $\mathrm{AgNO}_{3}$, etc. Therefore, it was determined to perform a green synthesis, which guarantees in many ways the generation of nanoparticles using more bioavailable reducers. Likewise, the synthesis was carried out at room temperature, in addition to using a very low concentration of the precursor salt, which implies low costs, simplicity and a lower environmental impact. On the other hand, Ramachandran et al. have identified some plant metabolites such as ascorbic acid, citric acid, cyclic peptide, ellagic acid, gallic acid, retinoic acid and sorbic acid; these have been identified as compounds responsible for the reduction and stabilization in the synthesis of AgNPs, in addition to providing specific properties with antibacterial, anticancer and antioxidant effects [27].

It is important to recognize the characteristic color change of AgNPs, as shown in Figure 1, where leaves and fruit peel extracts undergo a color change as silver ions are reduced, in this case, a yellowish color (the shell extract being a little more amber than the leaf extract) to an intense brown. The majority of authors described a yellowish color on the part of the extracts that, when reacting with $\mathrm{AgNO}_{3}$, change specifically from coffee to amber coffee. Santhosh et al. have managed to synthesize AgNPs from leaf extracts of $A$. muricata and describe the reduction of $\mathrm{Ag}$ ions by changing the color of the aqueous extract from a yellowish to brown color, in a given time [28].


Figure 1. AgNPs-PE and AgNPs-LE characterization: UV-Vis spectra of AgNPs-PE (a) and AgNPs-LE $(\mathbf{b})$ at different reaction times. FTIR spectrum (c) of leaf extracts (LE) and fruit peel extract (PE) of $A$. muricata. 


\subsection{Spectroscopic Characterization}

\subsubsection{Spectroscopic Characterization (UV-Vis)}

AgNPs offer an optical response known as surface plasmonic resonance (SPR). In addition, the size distribution and shape of AgNPs can be inferred through the amplitude of the band and the position of the maximum absorption band [29]. Based on this rationale, we selected colloidal solutions that had the best volume-volume ratio, both $\mathrm{AgNO}_{3}$, as well as extracts. Likewise, the reaction was monitored until observing the maximum absorption band with respect to time, which led to the identification of a six-hour nanoparticle formation period in both cases as shown in Figure 1; after this period of time the behavior is the same because it is the period when the nucleation and growth process of the AgNPs obtained ends. In the case of AgNPs-LE (Figure 1a), the maximum band absorption rate was recorded at $447 \mathrm{~nm}$, while AgNPs-PE (Figure 1b) have a maximum absorption band at $448 \mathrm{~nm}$. Silver nanoparticles usually record a maximum absorption band (RPS) that can appear from $370 \mathrm{~nm}$ [30] and up to $500 \mathrm{~nm}$. Some authors, such as Mallirkajuna et al., obtained AgNPs from natural extracts such as Ocimum sanctum, registering a maximum absorption band (SPR) at $436 \mathrm{~nm}$ [31]; on the other hand, Kumar et al. synthesized AgNPs from Annona squamosa shell extracts and reported a band (RPS) at $422 \mathrm{~nm}$ [32]; likewise, Vivek et al. obtained AgNPs using Annona squamosa leaf extracts reporting a band (RPS) at $444 \mathrm{~nm}$ [33].

In addition, it can be seen how the absorbance increases as the reaction time elapses; this is because more AgNPs are generated, and reflects the disappearance of ionic Ag. There are notable differences between AgNPs-PE and AgNPs-LE the absorption band of AgNPs$\mathrm{PE}$ is wider than AgNPs-LE. However, the absorbance is lower in AgNPs-LE, due to the size distribution found in both colloidal solutions. The results agree with what is established in the literature [32,33]: a quasi-spherical morphology and nanoparticles with sizes smaller than $50 \mathrm{~nm}$ can be expected in both cases, due to the position of the maximum position band after the $6 \mathrm{~h}$ of reaction; likewise, the same maximum absorption band has been observed for three consecutive months. The aqueous Annona muricata extracts used have an immense amount of metabolites like polyphenols, acetogenins, citric acid, etc. [13], some of which have already been reported as stabilizers of AgNPs in some other articles [34,35]. Jadhav and collaborators (2016) describe it as a layer that is responsible for stabilization, avoiding agglomeration and precipitation [36].

\subsubsection{Spectroscopic Characterization (FTIR) and Z Potential}

The FTIR spectrum, shown in Figure 1c, shows a characteristic absorption band at $1744 \mathrm{~cm}^{-1}$ (PE) and $1739 \mathrm{~cm}^{-1}$ (LE) characteristic of the vibrational mode of conjugated group $\mathrm{C}=\mathrm{O}$ (stretching), suggesting the presence of a $\gamma$-lactone- $\alpha, \beta$-unsaturated that distinguishes the vast majority of acetogenins [37,38]. Likewise, the vibrational mode corresponding to the groups $C=C$ (stretching) in $1619 \mathrm{~cm}^{-1}(\mathrm{PE})$ and $1643 \mathrm{~cm}^{-1}$ (LE) and $\mathrm{C}-\mathrm{O}$ (stretching) in $1373 \mathrm{~cm}^{-1}$ (PE) were recognized and $1339 \mathrm{~cm}^{-1}$ (LE), characteristic of the acetogenin molecule.

By the nature of the synthesis of the AgNPs, the AgNPs were expected to be surrounded by the extracts. This was confirmed by the $\mu_{\mathrm{e}}$ and $\mathrm{Z}$ potential with values of $-3.2 \mu \mathrm{mcm} / \mathrm{Vs}$ and $-34.4 \mathrm{mV}$, respectively, for AgNPs-PE, while the same parameters for AgNPs-LE was $1.3 \mu \mathrm{mcm} / \mathrm{Vs}$ and $23.3 \mathrm{mV}$, respectively. This effectively means that the nanoparticles could be surrounded by molecules such as acetogenins, among other metabolites, which help to maintain the stability of nanoparticles in aqueous solution [39].

\subsection{Morphological and Structural Characterization \\ 3.3.1. Elemental Analysis (SEM-EDS)}

An SEM/EDS analysis was carried out to corroborate the presence of the silver element in the AgNPs (LE and PE) obtained from leaf extracts and peel of A. muricata, then a comparison of the analysis graphs shows elementary chemical mapping of micrographs and cross-line scanning (Figure 2; Figure 3). 

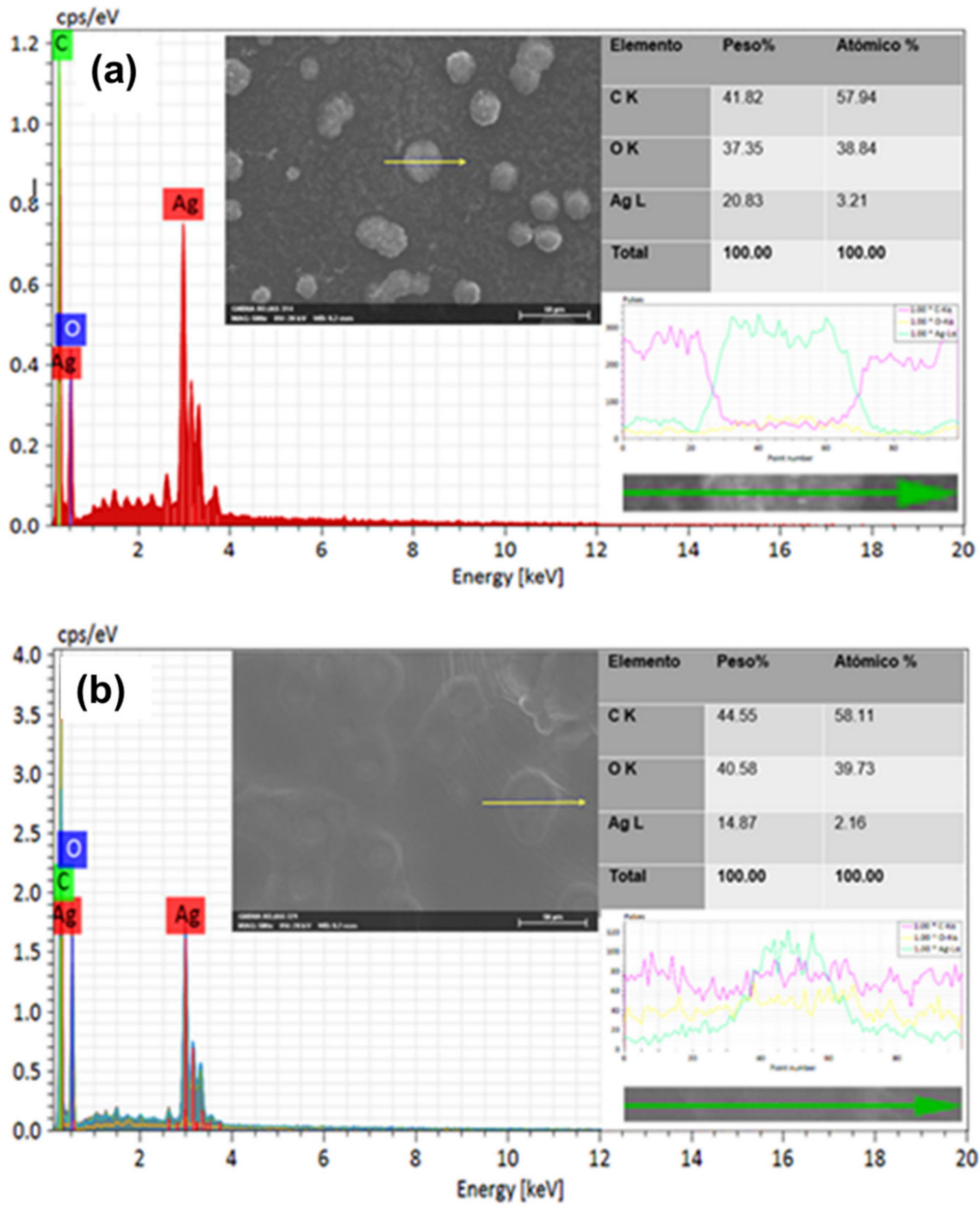

Figure 2. EDS analysis: comparison of the graphs of elementary analysis and cross-line scanning of the generated nanoparticles AgNPs-PE (a) and AgNPs-LE (b).
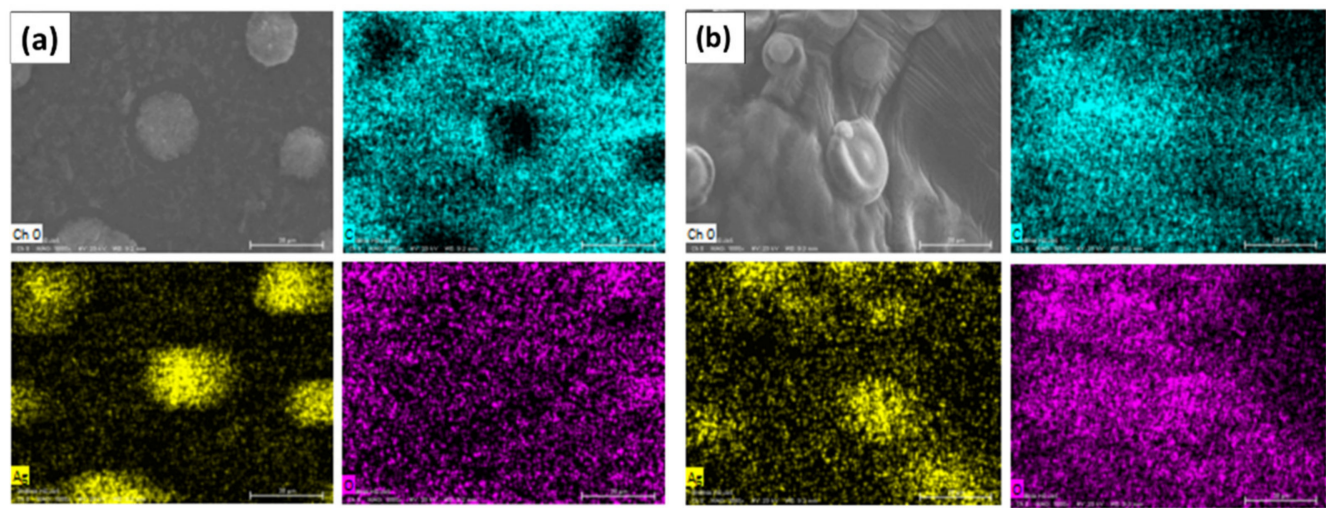

Figure 3. Chemical mapping of the elements carbon (blue color), silver (yellow color) and oxygen (purple color), (a) AgNPs-PE and (b) AgNPs-LE.

Regarding the micrographs, different agglomerates (clearer and brighter clusters) of nanoparticles can be observed in both images (Figure 2a,b). In the analysis by energy dispersion spectroscopy (EDS), it was possible to confirm the presence of the silver element in the sample, as can be seen in the spectrum of the same figures, while in the composition 
table, it is indicated that the percentage of silver is significant in both micrographs, both for AgNPs-PE and for AgNPs-LE; this is due to the concentration of $\mathrm{AgNO}_{3}$ from which the AgNPs were generated. In the same way, the EDS spectrum of the transverse line scan is shown in both; however, a greater intensity is reflected in the spectrum of AgNPsPE (Figure 2). This could be due to the amount of nanoparticles present in the selected agglomerate.

In the chemical mapping, the following elementary maps of both nanoparticles (AgNPs-PE and AgNPs-LE) were obtained. In Figure 2 we can observe that in both cases it is revealed that the surface of the entire sample consists of $\mathrm{Ag}, \mathrm{C}$ and $\mathrm{O}$, as presumably demonstrated in the EDS spectra. The carbon, oxygen and silver maps support the interpretation of the line scan, shown in Figure 2, agreeing that there is a greater intensity of the silver element in the AgNPs-PE. However, it is more than evident that the greater presence of $\mathrm{Ag}$ is present in the agglomerates. Likewise, it is observed that in the areas where there is more presence of $\mathrm{Ag}$, and less amount of $\mathrm{C}$ and $\mathrm{O}$ (Figure 3). Other authors demonstrate the same behavior in their samples [40,41], this could be due to the preparation of the sample, since the AgNPs agglomerate when the sample is dried.

\subsubsection{Morphological Analysis (TEM)}

Through Transmission Electron Microscopy (TEM), the size and shape of AgNPs previously synthesized with $A$. muricata leaves and fruit peel were elucidated. As can be seen in Figure 3a,b, it is evident that in both cases AgNPs with sizes smaller than $50 \mathrm{~nm}$ were obtained, fulfilling one of the main objectives of this investigation, since it offers better optical properties [42] and biocompatibility [43,44]. Currently, Santhosh et al., [28] have already synthesized AgNPs with leaf extracts of A. muricata. However, they obtained an average nanoparticle size of up to $103 \mathrm{~nm}$, which is not favorable for the objective application of this research; therefore, it was decided to experiment with different concentrations of both the precursor salt and the extracts. Likewise, Kumar et al. synthesized AgNPs from fruit peel extracts of $A$. squamosa, thus reporting a large polydispersity ranging from 20 to $60 \mathrm{~nm}$ [32], which is not viable for the application required in this project [43,44].

It should be noted that quasi-spherical AgNPs-PE and AgNPs-LE were obtained as shown in the micrographs of Figure 4(a2,b1). Other authors report it as irregular spherical or simply spherical forms. The ions capture an electron from the bioreducer and a nucleus or seed is formed. These are formed in the entire solution and there is a "competition" for the growth of the nuclei until the formation of the nanoparticles. Due to this competition between them, which is governed by thermodynamic parameters, a defined size is achieved and when the molecules are at this point they absorb superficially, acting as a protective layer to prevent the nanoparticles from continuing to grow and avoid collisions [27,45]. Likewise, little agglomeration is observed, which is important for the treatment in breast cancer cell lines, since they can be effectively dispersed in the medium.

On the other hand, the measurement of the diameter of the nanoparticles observed in the micrographs was carried out, both of the AgNPs-PE and of the AgNPs-LE by means of the ImageJ software, thus obtaining an average diameter size of $19.63 \pm 3.7 \mathrm{~nm}$ for AgNPs-LE (Figure 4(a1)) and, with a polydispersity of sizes ranging from 10 to $28 \mathrm{~nm}$. Likewise, the average diameter size of the AgNPs-PE (Figure 4(b2)) was obtained, which turned out to be $16.56 \pm 4.1 \mathrm{~nm}$, observing a polydispersity of greater range that goes from 8 to $26 \mathrm{~nm}$. It is evident that the AgNPs-PE have more uniform sizes, even less polydispersity is shown both in histograms and in the same micrographs with respect to the AgNPs in addition, very little agglomeration of AgNPs is recognized in both cases, at the same time observing sizes smaller than $50 \mathrm{~nm}$, thus corroborating the viability for the desired application. 

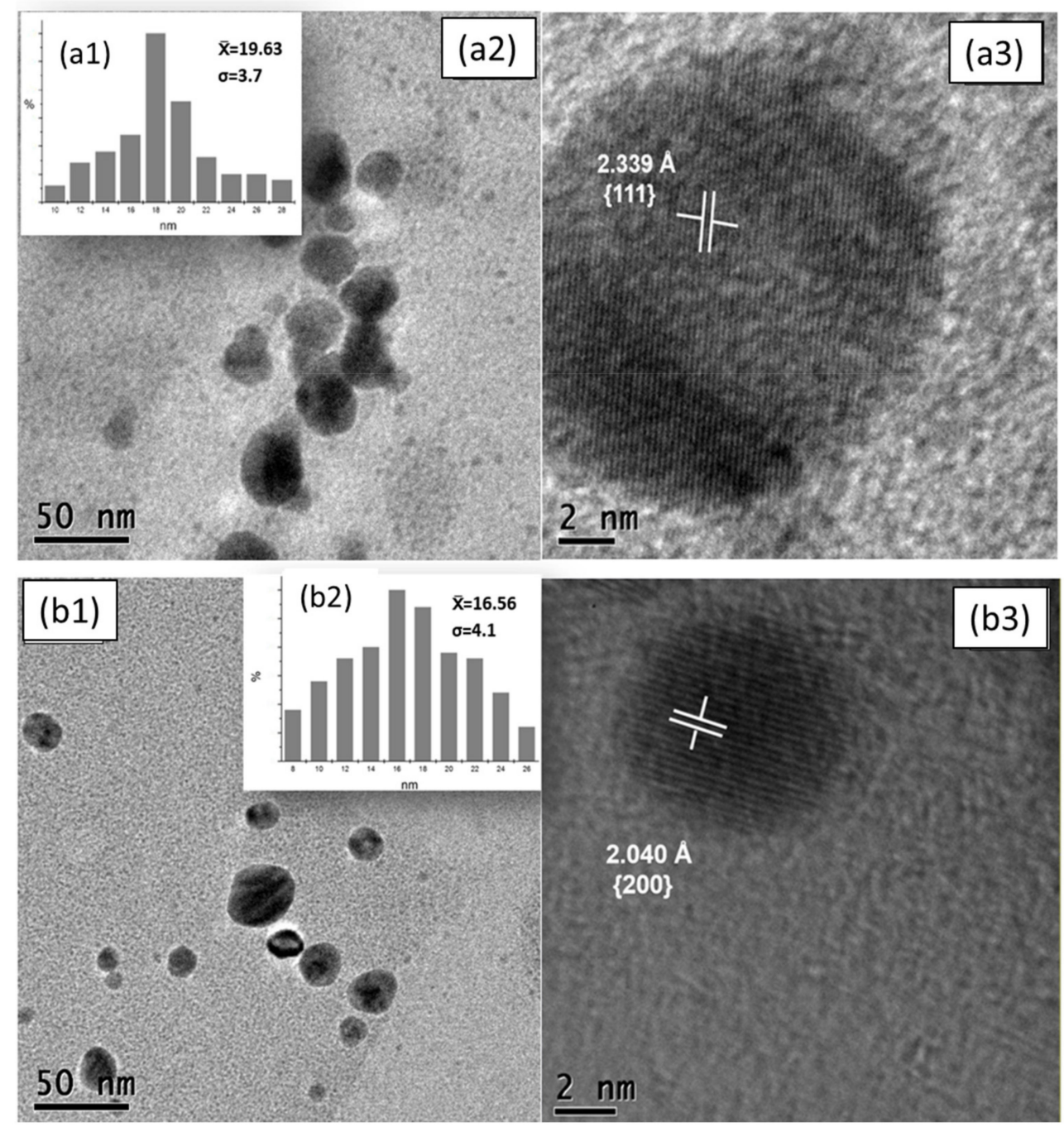

Figure 4. Micrograph obtained by TEM of AgNPs, as well as size distribution graph and HRTEM. The micrographs show the nanoparticles generated from the extracts of leaves and fruit peels of Annona muricata. The LE-AgNPs generated show an average diameter size of $19.63 \pm 3.7 \mathrm{~nm}$ (a1) and a quasi-spherical shape (a2). The inter-planar spaces with a distance of $2339 \AA$ were determined for the AgNPs-PE which corresponds to the family of planes (111) (a3). The LE-AgNPs generated show a quasi-spherical shape, individualized AgNPs can be seen without agglomerations (b1). The average diameter size of $16.56 \pm 4.1 \mathrm{~nm}$ for the AgNPs-PE (b2). The inter-planar distances of the AgNPs-LE were measured, obtaining a distance of $2040 \AA$, which corresponds to the family of planes (200) (b3).

The data obtained from the DLS measurements of hydrodynamic size and polydispersity index (PDI) were $41.16 \mathrm{~nm}$ and 0.481 for AgNPs-PE, while the measurements for AgNPs-LE were $48.39 \mathrm{~nm}$ and 0.643 .

Additionally, an analysis was conducted with HRTEM, with both AgNPs-PE and AgNPs-LE, in order to confirm that both AgNPs were formed by $\mathrm{Ag}^{0}$. The inter-planar spaces with a distance of $2339 \AA$ were determined for the AgNPs-PE (Figure 4(a3)), which corresponds to the family of planes (111); in the same way, the inter-planar distances of the AgNPs-LE were measured, obtaining a distance of $2040 \AA$, which corresponds to the family of planes (200) as shown in Figure 4(b3), taking as reference the JCPDS card 00-004-0783.

\subsection{Cell Viability Test}

The percentage of cell viability of the cell lines was determined, compared to different concentrations of AgNPs and extracts by the assay of 3-(4,5-dimethyl-2-thiazolyl)-2, 
5-diphenyl-2-tetrazoyl bromide (MTT) (Figure 5). We determined their inhibitory concentration $\left(\mathrm{IC}_{50}\right)$ after 3 days of treatment (Table 1$)$.
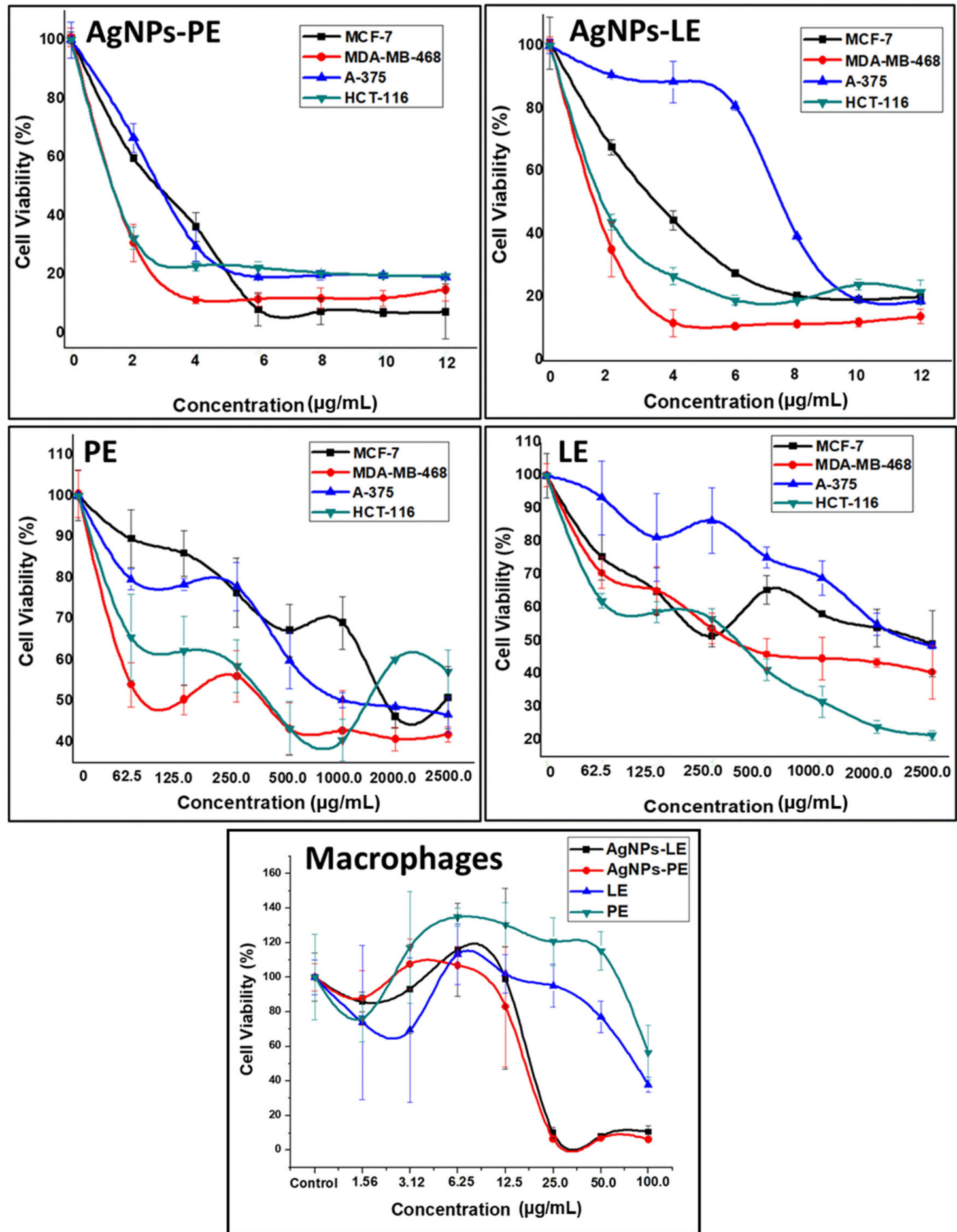

Figure 5. Graphs of the percentage of cell viability with respect to different concentrations of LE, PE, AgNPs-LE and AgNPs-PE. 
Table 1. Antiproliferative activities ( $\left.\mathrm{IC}_{50}(\mu \mathrm{g} / \mathrm{mL})\right)$ of AgNPs-PE, AgNPs-LE, PE in cancer cell lines and macrophages. All the experiments were performed in triplicate.

\begin{tabular}{cccccccccccc}
\hline \multirow{2}{*}{ Treatment } & \multicolumn{2}{c}{ MCF-7 } & \multicolumn{2}{c}{ MDA-MB-468 } & \multicolumn{2}{c}{ A-375 } & \multicolumn{3}{c}{ HCT-116 } & \multicolumn{2}{c}{ Macrophages } \\
\cline { 2 - 11 } & $\mathbf{I C}_{\mathbf{5 0}}$ & $\mathbf{R}^{\mathbf{2}}$ & $\mathbf{I C}_{\mathbf{5 0}}$ & $\mathbf{R}^{\mathbf{2}}$ & $\mathbf{I C}_{\mathbf{5 0}}$ & $\mathbf{R}^{\mathbf{2}}$ & $\mathbf{I C}_{\mathbf{5 0}}$ & $\mathbf{R}^{\mathbf{2}}$ & $\mathbf{I C}_{\mathbf{5 0}}$ & $\mathbf{R}^{\mathbf{2}}$ \\
\hline AgNPs-PE & 2.996 & 0.9309 & 1.685 & 0.9662 & 2.943 & 0.9728 & 1.285 & 0.9623 & 13.7 & 0.9980 \\
AgNPs-LE & 3.109 & 0.9806 & 1.910 & 0.9825 & 8.404 & 0.9672 & 2.004 & 0.9986 & 10.7 & 0.9792 \\
PE & 1278 & 0.9592 & 264.9 & 0.9676 & 1880 & 0.9934 & 309.3 & 0.9731 & - & - \\
LE & 2280 & 0.9803 & 776.4 & 0.9879 & 2478 & 0.9726 & 404.8 & 0.9708 & 68.97 & 0.9674 \\
\hline
\end{tabular}

The antitumor effect of LE has been previously reported [46]. Fattahi et al. reports an activity of the aqueous extracts against the MCF-7 line with an $\mathrm{IC}_{50}$ of $2000 \mu \mathrm{g} / \mathrm{mL}$ relatively similar to those that we have obtained [47]. As shown in Table 1, the $\mathrm{IC}_{50}$ values for the PE were lower than LE for all tumor cell lines tested. Indeed, breast cancer cells have been demonstrated to be more sensitive to PE than LE, reducing its $\mathrm{IC}_{50}$ by $65.88 \%$ and $43.95 \%$ for MDA-MB-468 and MCF-7, respectively. In addition, both A-375 melanoma and HCT-116 colon cancer cell lines showed similar sensitivity to PE with $24.14 \%$ and $23.6 \%$ of $\mathrm{IC}_{50}$ decrease in comparison to LE.

On the other hand, our results demonstrated that all cancer cell lines were drastically more sensitive to our biosynthesized AgNPs than extract, as they achieved a better effect with $99 \%$ lower concentrations. In this context, several studies demonstrated that the AgNPs had an important anticancer activity. AgNPs synthesized using other plants demonstrated the anti-proliferative activity against several cancer cell lines including human colorectal adenocarcinoma, kidney and cervix [48]. The biosynthesized AgNPs based on Commelina nudiflora aqueous extract showed reduced cell viability and increased cytotoxicity in HCT-116 colon cancer cells with $\mathrm{IC}_{50}$ concentration of 200 and $100 \mu \mathrm{g} / \mathrm{mL}$, respectively [49]. Saratale and collaborators prepared AgNPs using Taraxacum officinale showing their high cytotoxic effect against human liver cancer cells (HepG2) using an IC 50 about $60 \mu \mathrm{g} / \mathrm{mL}$ [50]. The Nostoc linckia based AgNPs had anticancer activity against breast cancer cell MCF-7 with an $\mathrm{IC}_{50}$ of $27.79 \mu \mathrm{g} / \mathrm{mL}$ [51].

To our surprise, our results showed that AgNPs-PE were more potent than AgNPs-LE reaching $64.98 \%, 37 \%, 11.78 \%$ and $3.63 \%$ more effectiveness in HCT-116, A-375, MDA-MB468 and MCF-7, respectively. In addition, the $\mathrm{IC}_{50}$ obtained have been much lower than those described in the literature since with an $\mathrm{IC}_{50}$ of only $1.685 \mu \mathrm{g} / \mathrm{mL}$, our AgNPs-PE from $A$. muricata were able to induce cytotoxicity to MDA-MB-468, a triple negative breast cancer cell line (do not express estrogen receptor (ER), progesterone receptor (PR), and do not have HER-2/Neu amplification), characterized by a poor outcome compared to the other subtypes of breast cancer [52]. To the best of our knowledge, the only study that analyzes the antitumor effect of AgNPs-PE from A. muricata was in an AMJ-13 breast cancer cell line $\left(\mathrm{ER}^{-}, \mathrm{PR}^{-}\right.$and $\left.\mathrm{HER} 2 / \mathrm{neu}^{+}\right)$and reported an $\mathrm{IC}_{50}$ of $17.34 \mu \mathrm{g} / \mathrm{mL}$ using $\mathrm{AgNPs}$ synthetized from A. muricata stock solution 10-fold more concentrated than ours [53]. This could be due to the geographical origin of the plant, the season in which both the leaves and the peel of the fruit were collected and even its age [54-56]. There are specific investigations of the Annona muricata species, where significant variations in the biochemical composition are reflected depending on the collection season [57].

A comparison between the tumor cell lines (MCF-7, MDA-MB-468, HCT-116 and A-375) and the macrophage cell line was established in order to define the selective activity of the AgNPs and extract through the determination of the in vitro therapeutic index (TI) (Table 2). The ratio of the toxic dose to the therapeutic dose (In vitro $\mathrm{TI}=\mathrm{IC}_{50}$ non-tumor cell line/IC 50 tumor cell line) is defined as the in-vitro TI of a drug [58]. In macrophages we found that the cytotoxic effect of LE extracts was remarkably higher. In fact, our results showed that LE treatment is more cytotoxic for macrophages than for cancer cells. This could be due to alterations in the cytoskeletal function as a result of the treatment with LE and possibly due to the specific function of macrophages. Here the importance of treatment 
with PE stands out, since at high concentrations there are no indications that it is cytotoxic against macrophages [59]. This could be due to the phytochemicals difference existing between the LE and PE extracts such as phenolic compounds [39], which have reported apoptosis in macrophages [40].

Table 2. Therapeutic indexes $(\mu \mathrm{g} / \mathrm{mL})$ for AgNPs-PE, AgNPs-LE, PE and LE in different tumor cell lines compared to the macrophage cell line. ${ }^{*} \mathrm{ND}$ (not determined).

\begin{tabular}{ccccc}
\hline Treatment & MCF-7 & MDA-MB-468 & A375 & HCT-116 \\
\hline AgNPS-PE & 4.34 & 8.13 & 4.655 & 10.66 \\
AgNPS-LE & 3.44 & 5.602 & 1.273 & 5.245 \\
PE & ND $^{*}$ & ND $^{*}$ & ND $^{*}$ & ND $^{*}$ \\
LE & 0.030 & 0.088 & 0.027 & 0.170 \\
\hline
\end{tabular}

Furthermore, TI was better by far for almost all cell lines treated by AgNPs-PE (Table 2). The best TI was achieved by HCT-116 and MDA-MB-468 (TIs = 10.66 and 8.13 respectively). It should be noted that macrophages are cells of the immune system that are found in tissues and serve as protection against external agents. Our results suggest that macrophages are less susceptible to damage from acetogenins, and it could be that their effect is directly on cancer cells. This is due to the rapid proliferation of cancer cells, since they require high levels of energy, so they may be more sensitive to their decline and have important physiological changes [60]. Some authors attribute the effect of aqueous extracts to the release of $\mathrm{NO}$ and TNF- $\alpha$, which is capable of upregulating the expression of iNOS and $\mathrm{TNF}-\alpha$ through the transactivation of NF- $\mathrm{B}$, and this may be a mechanism by the which this herbal medicine causes its therapeutic effects [61]. The mechanism of action of the acetogenins in cancer cells has been reported in terms of apoptotic cell death and control of the cell cycle checkpoint [62]. Other authors suggest that the presence of AgNPs induces the formation of reactive oxygen species, which are considered the main source of DNA damage $[63,64]$; it could be then inferred that both acetogenins and AgNPs target cells with the greatest energy need, such as cancer cells, which justifies our results.

After the determination of the anti-tumor activity of the different treatments against the tumor cell lines, we selected MDA-MB-468 and MCF-7 lines, in order to analyze its proliferation and morphological changes after 6 days of induction of different compounds and determine if the use of $\mathrm{IC}_{50}$ will achieve total cell death. Our results demonstrated that unlike cells treated with high doses of extracts, lower doses of the AgNPs caused total cell death (Figure 6).

In fact, using SEM we observed that both MCF-7 and MDA-MB-468 control cells were abundant, highly adherent to the substrate and its surface covered by multiple microvillous extensions. However, treatment of MCF-7 and MDA-MB-468 cells with $2280 \mu \mathrm{g} / \mathrm{mL}$ and $776.4 \mu \mathrm{g} / \mathrm{mL}$ of the LE extract, respectively, results in a slight effect on the proliferation of the cell lines- a little more marked in the MDA-MB-468 cells. Even better, the treatment with $1278 \mu \mathrm{g} / \mathrm{mL}$ and $264.9 \mu \mathrm{g} / \mathrm{mL}$ of PE extract has achieved clear cell death with a concomitant decrease in cell density in both MCF-7 and MDA-MB-468 cell lines, respectively. This death has been further accentuated with the use of $2.996 \mu \mathrm{g} / \mathrm{mL}$ and $3.109 \mu \mathrm{g} / \mathrm{mL}$ of AgNPs-LE treatment in both cell lines. Moreover, a similar effect has been observed with the use of even smaller amounts of AgNPs-PE $(1.685 \mu \mathrm{g} / \mathrm{mL}$ and $1.910 \mu \mathrm{g} / \mathrm{mL})$. The treatment with PE, AgNPs-LE and AgNPs-PE showed that only a few round cells remained anchored to the substrate, showing in most of the cases disrupted cytoplasmic membranes and multiple "pores" with different sizes (yellow arrows, Figure 6f). Moreover, cells presented a "flat surface" due to the loss of microvilli and filopodia structures and the apparition of apoptotic bodies a clear signal of death by apoptosis (Figure 6). These results are in concordance with those reported by Jabir and collaborators in THP-1 and AMJ-13 cell lines [53]. 


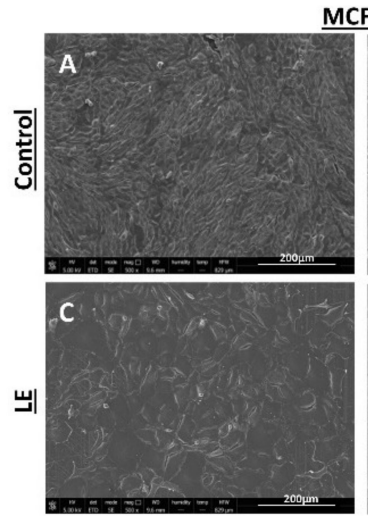

MCF-7
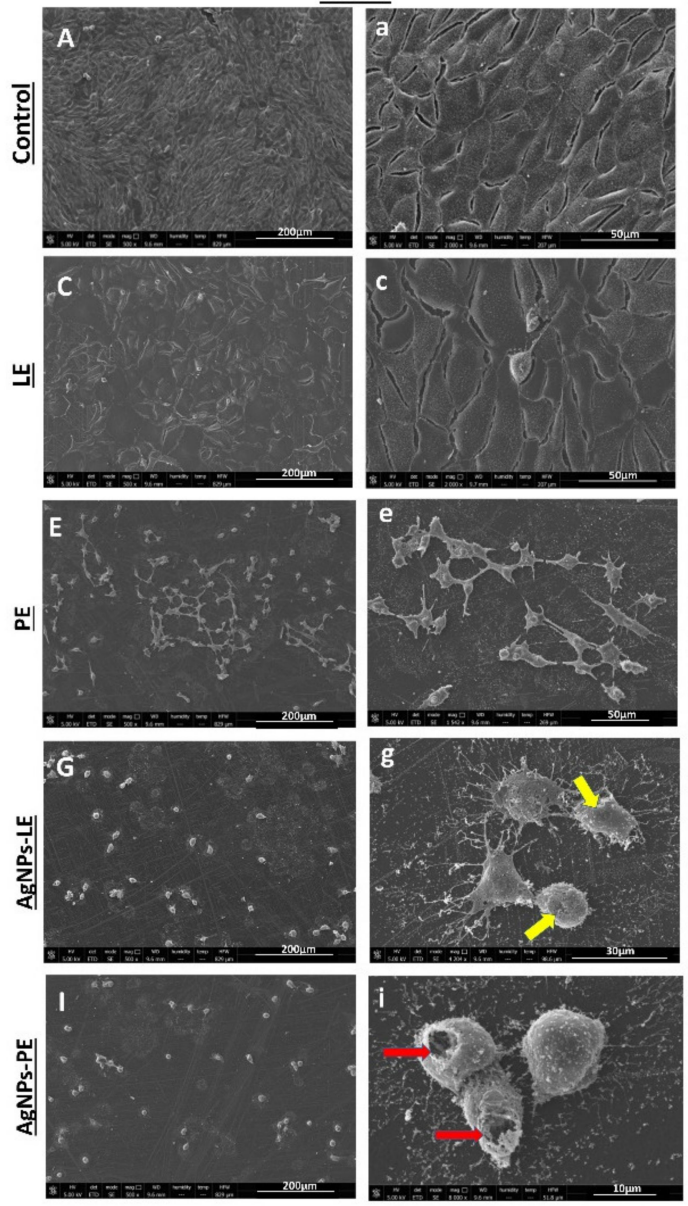
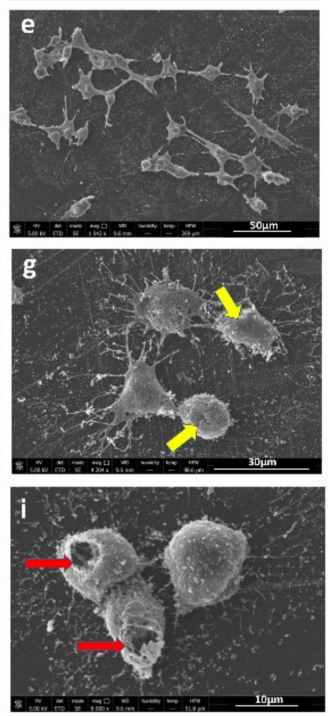
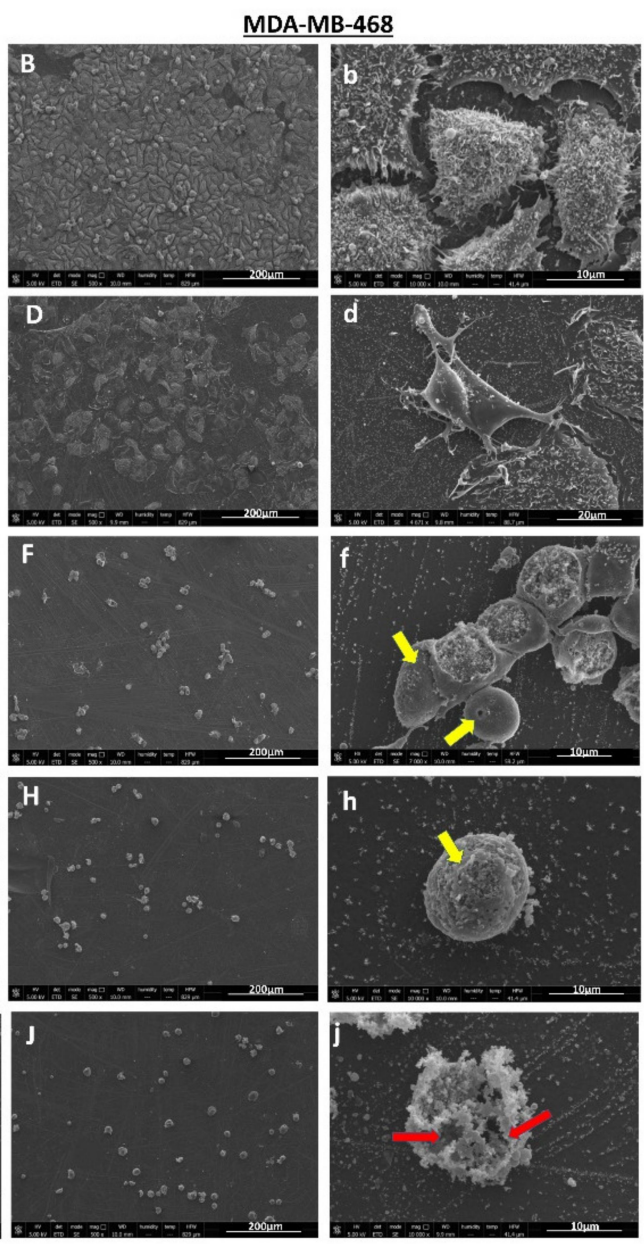

Figure 6. Microscopy micrographs of MCF-7 and MDA-MB-468 cells after 6 days of $\mathrm{IC}_{50}$ treatments with different compounds. Cell controls are shown in $(\mathbf{A}, \mathbf{a}, \mathbf{B}, \mathbf{b})$ under treatment with LE extract $(\mathbf{C}, \mathbf{c}, \mathbf{D}, \mathbf{d})$ showed cells with epithelial form strongly adhered to the surface of the culture coverslip, and PE show cells with loss of microvilli (E,e,F), in addition to multiple pores (arrows yellow) (f), the micrographs of the cells treated with AgNPs-LE show a decrease in cells compared to the controls $(\mathbf{G}, \mathbf{H})$. Cells treated with NPs also showed pore formation (yellow arrows, $\mathbf{g}, \mathbf{h}$ ) and a flatter cell surface than controls, due to the loss of microvilli and filopod structures. Cells treated with AgNPs-PE (I,J) also show cell decrease, in addition to giant cells with destructured cytoplasmic membrane (red arrows, $\mathbf{i}, \mathbf{j})$ Scale bar $(200-10 \mu \mathrm{m})$.

Moutin et al. [65] attribute the morphological deteriorations in cells exposed to AgNPs to actin interference with the structure and functions of the cytoskeleton. Damage to the cytoskeleton could result from calcium fluctuations and genetic dysregulation; this creates coherence, since the +ions that are released from the nanoparticles are involved in cell signaling cascades with the activation of $\mathrm{Ca}^{2+}$ release that further activates catabolic enzymes and damages mitochondrial membranes. Furthermore, the repeated entry and exit of calcium into the mitochondria could result in damage to the mitochondrial membrane, resulting in the production of ROS and inhibition of ATP synthesis [66]. Knowing the effects that the AgNPs and the acetogenins contained in the extracts have on the breast cancer cell lines, it is easy to adjudge that the cytotoxic effect will be potentiated when the nanoparticles are formed with the extracts, since they will have a duplex function. Likewise, it must be recognized that the cytotoxic effect of the AgNPs will be greater than the extracts due to the concentrations used for their generation.

The reactive oxygen species (ROS) at the cellular level are responsible for inducing DNA damage and, therefore, leading to cell death. Some authors report studies where biosynthesized AgNPs from natural extracts, through redox reactions, where the reducing agent is usually a set of polyphenols present in the extracts, whose function is to cause oxidative stress, which leads to cell death through the mitochondria [67]. Likewise, it 
is known that the possible mechanism involved in cellular toxicity induced by AgNPs, triggers reactive oxygen species (ROS) by inhibiting the synthesis of intracellular antioxidants [63].

\section{Conclusions}

In this manuscript we demonstrate, for the first time, that even though the leaf of the Annona muricata has been traditionally considered "the cancer killer" in conventional medicine, the peel extract of this fruit has an even more powerful antitumor effect. In fact, we were able to produce nanoparticles, with a potent in-vitro antitumor effect, from concentrations of leaves (LE) and peel (PE) of fruit of A. muricata extracts much lower than those reported by other authors. Moreover, this difference is accentuated with AgNPs where the destruction of cancer cells was achieved using concentrations that do not exceed $3 \mu \mathrm{g} / \mathrm{mL}$ with a better therapeutic index in the different tumor strains. Our results are very promising and provide the basis for the development of in-vivo experiments for their validation. In conclusion, we present a low-cost one-step experimental setup to generate AgNPs-PE, whose biocompatibility and potent therapeutic effect make it a very attractive tool worthy of being exploited.

Author Contributions: Conceptualization, H.B. and M.G.G.-P.; methodology, R.A.M.-L.; software, S.A.N.-M.; validation, E.M.-M., L.A.-F. and R.G.-C.; formal analysis, J.A.M.; research, M.G.G.-P. and L.A.-F.; resources, J.A.M.; data curation, Y.J.-M.; writing - preparation of the original draft, M.G.G.-P.; writing - revision and editing, H.B., M.G.G.-P. and R.A.M.-L.; Visualization, S.A.N.-M.; supervision, H.B. and R.A.M.-L.; project administration, J.A.M.; funding acquisition, H.B. All authors have read and agreed to the published version of the manuscript.

Funding: This research was supported by Fundacion Empresa Universidad de Granada (Project PR/18/001), Fundación Mutua Madrileña (Project FMM-AP16683-2017), Consejería de Salud Junta de Andalucía (PI-0089-2017) and Instituto de Salud Carlos III (RTI2018-101309-B-C22).

Data Availability Statement: Not applicable.

Acknowledgments: M.G.G.-P. acknowledges CONACYT financial support. Thanks to the ImageJ development team (especially Wayne Rasband).

Conflicts of Interest: The authors declare no conflict of interest.

\section{References}

1. Siegel, R.L.; Miller, K.D.; Fuchs, H.E.; Jemal, A. Cancer Statistics, 2021. CA Cancer J. Clin. 2021, 71, 7-33. [CrossRef]

2. Sung, H.; Ferlay, J.; Siegel, R.L.; Laversanne, M.; Soerjomataram, I.; Jemal, A.; Bray, F. Global cancer statistics 2020: GLOBOCAN estimates of incidence and mortality worldwide for 36 cancers in 185 countries. CA Cancer J. Clin. 2021, 71, 209-249. [CrossRef]

3. Vasan, N.; Baselga, J.; Hyman, D.M. A view on drug resistance in cancer. Nat. Cell Biol. 2019, 575, 299-309. [CrossRef] [PubMed]

4. Boulaiz, H.; Alvarez, P.J.; Ramirez, A.; Marchal, J.A.; Prados, J.; Rodríguez-Serrano, F.; Perán, M.; Melguizo, C.; Aranega, A. Nanomedicine: Application Areas and Development Prospects. Int. J. Mol. Sci. 2011, 12, 3303-3321. [CrossRef]

5. Chernousova, S.; Epple, M. Silver as Antibacterial Agent: Ion, Nanoparticle, and Metal. Angew. Chem. Int. Ed. 2013, 52, 1636-1653. [CrossRef] [PubMed]

6. Zhang, X.-F.; Liu, Z.-G.; Shen, W.; Gurunathan, S. Silver nanoparticles: Synthesis, characterization, proper-ties, applications, and therapeutic approaches. Int. J. Mol. Sci. 2016, 17, 1534. [CrossRef] [PubMed]

7. Elsupikhe, R.F.; Shameli, K.; Ahmad, M.B.; Ibrahim, N.A.; Zainudin, N. Green sonochemical synthesis of silver nanoparticles at varying concentrations of K-carrageenan. Nanoscale Res. Lett. 2015, 10, 1-8. [CrossRef] [PubMed]

8. Shameli, K.; Ahmad, M.B.; Yunus, W.M.Z.W.; Ibrahim, N.A.; Gharayebi, Y.; Sedaghat, S. Synthesis of silver/montmorillonite nanocomposites using $\gamma$-irradiation. Int. J. Nanomed. 2010, 5, 1067. [CrossRef]

9. Deepak, V.; Umamaheshwaran, P.S.; Guhan, K.; Nanthini, R.A.; Krithiga, B.; Jaithoon, N.M.H.; Gurunathan, S. Synthesis of gold and silver nanoparticles using purified URAK. Colloids Surf. B Biointerfaces 2011, 86, 353-358. [CrossRef]

10. Gurunathan, S.; Han, J.W.; Park, J.-H.; Kim, E.S.; Choi, Y.-J.; Kwon, D.-N.; Kim, J.-H. Reduced graphene oxide-silver nanoparticle nanocomposite: A potential anticancer nanotherapy. Int. J. Nanomed. 2015, 10, 6257-6276. [CrossRef]

11. Gurunathan, S.; Han, J.; Park, J.H.; Kim, J.-H. A green chemistry approach for synthesizing biocompatible gold nanoparticles. Nanoscale Res. Lett. 2014, 9, 248. [CrossRef] [PubMed]

12. Kalimuthu, K.; Babu, R.S.; Venkataraman, D.; Bilal, M.; Gurunathan, S. Biosynthesis of silver nanocrystals by Bacillus licheniformis. Colloids Surf. B Biointerfaces 2008, 65, 150-153. [CrossRef] [PubMed] 
13. Javed, B.; Ikram, M.; Farooq, F.; Sultana, T.; Mashwani, Z.-U.-R.; Raja, N.I. Biogenesis of silver nanoparticles to treat cancer, diabetes, and microbial infections: A mechanistic overview. Appl. Microbiol. Biotechnol. 2021, 105, 2261-2275. [CrossRef]

14. Alonso-Castro, A.J.; Villarreal, M.L.; Salazar-Olivo, L.A.; Gomez-Sanchez, M.; Dominguez, F.; Garcia-Carranca, A. Mexican medicinal plants used for cancer treatment: Pharmacological, phytochemical and ethnobotanical studies. J. Ethnopharmacol. 2011, 133, 945-972. [CrossRef] [PubMed]

15. Kitamura, M.C.; Lemos, E.E.P. Enxertia precoce da gravioleira (Annona muricata L.). Rev. Bras. Frutic. 2004, 26, 186-188. [CrossRef]

16. Moghadamtousi, S.; Fadaeinasab, M.; Nikzad, S.; Mohan, G.; Ali, H.; Kadir, H. Annona muricata (An-nonaceae): A review of its traditional uses, isolated acetogenins and biological activities. Int. J. Mol. Sci. 2015, 16, 15625-15658. [CrossRef] [PubMed]

17. Fuentes, L.M.H.; Vildózola, A.C.; Santos, M.O.; Carrasco, J.V. El Chacuatete, Idiarthron subquadratum, en Guanábana, Annona muricata. Southwest. Antomol. 2016, 41, 855-864. [CrossRef]

18. Correa-Gordillo, J.; Ortiz, D.; Larrahondo, J.; Sánchez-Mejía, M.; Pachón, H. Antioxidant activity in soursop (Annona muricata L.): A literature review. BLACPMA 2012, 11, 111-126.

19. George, V.C.; Kumar, D.N.; Suresh, P.; Kumar, R.A. Antioxidant, DNA protective efficacy and HPLC analysis of Annona muricata (soursop) extracts. J. Food Sci. Technol. 2015, 52, 2328-2335. [CrossRef]

20. Mittal, A.K.; Chisti, Y.; Banerjee, U.C. Synthesis of metallic nanoparticles using plant extracts. Biotechnol. Adv. 2013, 31, 346-356. [CrossRef]

21. Schlie-Guzmán, M.A.; González-Esquinca, A.R.; Luna-Cazáres, L.M. Acetogenins from Annonaceae: Anti-proliferative effect in neoplastic cell lines. Lat. Am. Caribb. Bull. Med. Aromat. Plants 2009, 8, 245-257.

22. Moghadamtousi, S.Z.; Karimian, H.; Rouhollahi, E.; Paydar, M.; Fadaeinasab, M.; Kadir, H.A. Annona muricata leaves induce G 1 cell cycle arrest and apoptosis through mitochondria-mediated pathway in human HCT-116 and HT-29 colon cancer cells. J. Ethnopharmacol. 2014, 156, 277-289. [CrossRef]

23. Gajalakshmi, S.; Vijayalakshmi, S.; Devi, R.V. Phytochemical and pharmacological properties of Annona muricata: A review. Int. J. Pharm. Pharm. Sci. 2012, 4, 3-6.

24. Gavamukulya, Y.; Abou-Elella, F.; Wamunyokoli, F.; Ael-Shemy, H. Phytochemical screening, antioxidant activity and in vitro anticancer potential of ethanolic and water leaves extracts of Annona muricata (Graviola). Asian Pac. J. Trop. Med. 2014, 7 , S355-S363. [CrossRef]

25. Gajendran, B.; Chinnasamy, A.; Durai, P.; Raman, J.; Ramar, M. Biosynthesis and characterization of silver nanoparticles from Datura inoxia and its apoptotic effect on human breast cancer cell line MCF7. Mater. Lett. 2014, 122, 98-102. [CrossRef]

26. Cáceres, B.; Ramirez, A.; Carrillo, E.; Jimenez, G.; Griñán-Lisón, C.; López-Ruiz, E.; Jiménez-Martínez, Y.; Marchal, J.A.; Boulaiz, H. Deciphering the Mechanism of Action Involved in Enhanced Suicide Gene Colon Cancer Cell Killer Effect Mediated by Gef and Apoptin. Cancers 2019, 11, 264. [CrossRef]

27. Rajan, R.; Chandran, K.; Harper, S.L.; Yun, S.-I.; Kalaichelvan, P.T. Plant extract synthesized silver nanoparticles: An ongoing source of novel biocompatible materials. Ind. Crop. Prod. 2015, 70, 356-373. [CrossRef]

28. Santhosh, S.; Yuvarajan, R.; Natarajan, D. Annona muricata leaf extract-mediated silver nanoparticles synthesis and its larvicidal potential against dengue, malaria and filariasis vector. Parasitol. Res. 2015, 114, 3087-3096. [CrossRef] [PubMed]

29. Jain, P.K.; El-Sayed, I.H.; El-Sayed, M.A. Au nanoparticles target cancer. Nano Today 2007, 2, 18-29. [CrossRef]

30. Morales-Luckie, R.A.; Sánchez-Mendieta, V.; Olea-Mejia, O.; Vilchis-Nestor, A.R.; López-Téllez, G.; Varela-Guerrero, V.; Huerta, L.; Arenas-Alatorre, J. Facile solventless synthesis of a nylon-6, 6/silver nano-particles composite and its XPS study. Int. J. Polym. Sci. 2013, 2013. [CrossRef]

31. Mallikarjuna, K.; Narasimha, G.; Dillip, G.; Praveen, B.; Shreedhar, B.; Lakshmi, C.S.; Reddy, B.; Raju, B.D.P. Green synthesis of silver nanoparticles using Ocimum leaf extract and their characterization. Dig. J. Nanomater. Biostruct. 2011, 6, 181-186.

32. Kumar, R.; Roopan, S.M.; Prabhakarn, A.; Khanna, V.G.; Chakroborty, S. Agricultural waste Annona squa-mosa peel extract: Biosynthesis of silver nanoparticles. Spectrochim. Acta Part A Mol. Biomol. Spectrosc. 2012, 90, 173-176. [CrossRef]

33. Vivek, R.; Thangam, R.; Muthuchelian, K.; Gunasekaran, P.; Kaveri, K.; Kannan, S. Green biosynthesis of silver nanoparticles from Annona squamosa leaf extract and its in vitro cytotoxic effect on MCF-7 cells. Process. Biochem. 2012, 47, 2405-2410. [CrossRef]

34. Hosseini-Koupaei, M.; Shareghi, B.; Saboury, A.A.; Davar, F.; Sirotkin, V.A.; Hosseini-Koupaei, M.H.; Enteshari, Z. Catalytic activity, structure and stability of proteinase $\mathrm{K}$ in the presence of biosynthesized CuO nanoparticles. Int. J. Biol. Macromol. 2019, 122, 732-744. [CrossRef]

35. Nasrollahzadeh, M.; Sajjadi, M.; Dadashi, J.; Ghafuri, H. Pd-based nanoparticles: Plant-assisted biosynthesis, characterization, mechanism, stability, catalytic and antimicrobial activities. Adv. Colloid Interface Sci. 2020, 276, 102103. [CrossRef]

36. Jadhav, K.; Dhamecha, D.; Bhattacharya, D.; Patil, M. Green and ecofriendly synthesis of silver nanoparticles: Characterization, biocompatibility studies and gel formulation for treatment of infections in burns. J. Photochem. Photobiol. B Biol. 2016, 155, 109-115. [CrossRef] [PubMed]

37. Garcia, K. Isolation and Structural Characterization of Acetogenins Obtained from Annona cherimolia and Annona muricata Seeds. Genotoxic Evaluation and Chemotherapeutic Potential. Ph.D. Thesis, National School Biological Deficiencies Mexico, National Polytechnic Institute, Mexico City, Mexico, 2009.

38. Rieser, M.J.; Gu, Z.-M.; Fang, X.-P.; Zeng, L.; Wood, K.V.; McLaughlin, J.L. Five Novel Mono-tetrahydrofuran Ring Acetogenins from the Seeds of Annona muricata. J. Nat. Prod. 1996, 59, 100-108. [CrossRef] [PubMed] 
39. Ivanov, M.R.; Bednar, H.R.; Haes, A.J. Investigations of the Mechanism of Gold Nanoparticle Stability and Surface Functionalization in Capillary Electrophoresis. ACS Nano 2009, 3, 386-394. [CrossRef] [PubMed]

40. Durán, N.; Marcato, P.D.; de Souza, G.I.H.; Alves, O.L.; Esposito, E. Antibacterial Effect of Silver Nanoparticles Produced by Fungal Process on Textile Fabrics and Their Effluent Treatment. J. Biomed. Nanotechnol. 2007, 3, 203-208. [CrossRef]

41. Kubo, A.M.; Gorup, L.F.; Amaral, L.S.; Rodrigues-Filho, E.; de Camargo, E.R. Heterogeneous Microtubules of Self-assembled Silver and Gold Nanoparticles Using Alive Biotemplates. Mater. Res. 2018, 21, 21. [CrossRef]

42. Auffan, M.; Rose, J.; Bottero, J.-Y.; Lowry, G.V.; Jolivet, J.-P.; Wiesner, M.R. Towards a definition of inorganic nanoparticles from an environmental, health and safety perspective. Nat. Nanotechnol. 2009, 4, 634-641. [CrossRef] [PubMed]

43. Liu, X.; Yang, Y.; Mao, L.; Li, Z.; Zhou, C.; Liu, X.; Zheng, S.; Hu, Y. SPR quantitative analysis of direct detection of atrazine traces on Au-nanoparticles: Nanoparticles size effect. Sens. Actuators B Chem. 2015, 218, 1-7. [CrossRef]

44. El-Sayed, I.H.; Huang, X.; El-Sayed, M.A. Selective laser photo-thermal therapy of epithelial carcinoma us-ing anti-EGFR antibody conjugated gold nanoparticles. Cancer Lett. 2006, 239, 129-135. [CrossRef]

45. Ahmed, S.; Ahmad, M.; Swami, B.L.; Ikram, S. A review on plants extract mediated synthesis of silver nanoparticles for antimicrobial applications: A green expertise. J. Adv. Res. 2016, 7, 17-28. [CrossRef]

46. Wahab, S.M.A.; Jantan, I.; Haque, A.; Arshad, L. Exploring the Leaves of Annona muricata L. as a Source of Potential Antiinflammatory and Anticancer Agents. Front. Pharmacol. 2018, 9, 661. [CrossRef] [PubMed]

47. Fattahi, S.; Ardekani, A.M.; Zabihi, E.; Abedian, Z.; Mostafazadeh, A.; Pourbagher, R.; Akhavan-Niaki, H. Antioxidant and Apoptotic Effects of an Aqueous Extract of Urtica dioica on the MCF-7 Human Breast Cancer Cell Line. Asian Pac. J. Cancer Prev. 2013, 14, 5317-5323. [CrossRef] [PubMed]

48. Raghunandan, D.; Ravishankar, B.; Sharanbasava, G.; Mahesh, D.B.; Harsoor, V.; Yalagatti, M.S.; Bhaga-Wanraju, M.; Venkataraman, A. Anti-cancer studies of noble metal nanoparticles synthesized using different plant extracts. Cancer Nanotechnol. 2011, 2, 57-65. [CrossRef] [PubMed]

49. Kuppusamy, P.; Ichwan, S.J.A.; Al-Zikri, P.N.H.; Suriyah, W.H.; Soundharrajan, I.; Govindan, N.; Maniam, G.P.; Yusoff, M.M. In Vitro Anticancer Activity of Au, Ag Nanoparticles Synthesized Using Commelina nudiflora L. Aqueous Extract Against HCT-116 Colon Cancer Cells. Biol. Trace Element Res. 2016, 173, 297-305. [CrossRef]

50. Saratale, R.G.; Benelli, G.; Kumar, G.; Kim, D.S.; Saratale, G.D. Bio-fabrication of silver nanoparticles using the leaf extract of an ancient herbal medicine, dandelion (Taraxacum officinale), evaluation of their antioxidant, anticancer potential, and antimicrobial activity against phytopathogens. Environ. Sci. Pollut. Res. 2017, 25, 10392-10406. [CrossRef]

51. El-Naggar, N.E.-A.; Hussein, M.H.; El-Sawah, A.A. Bio-fabrication of silver nanoparticles by phycocyanin, characterization, in vitro anticancer activity against breast cancer cell line and in vivo cytotxicity. Sci. Rep. 2017, 7, 10844. [CrossRef]

52. Chavez, K.J.; Garimella, S.V.; Lipkowitz, S. Triple negative breast cancer cell lines: One tool in the search for better treatment of triple negative breast cancer. Breast Dis. 2011, 32, 35-48. [CrossRef]

53. Jabir, M.; Saleh, Y.; Sulaiman, G.; Yaseen, N.; Sahib, U.; Dewir, Y.; Alwahibi, M.; Soliman, D. Green Synthesis of Silver Nanoparticles Using Annona muricata Extract as an Inducer of Apoptosis in Cancer Cells and Inhibitor for NLRP3 Inflammasome via Enhanced Autophagy. Nanomaterials 2021, 11, 384. [CrossRef]

54. Valares, M.C. Variación del Metabolismo Secundario en Plantas Debida al Genotipo y al Ambiente; Universidad de Extremadura: Badajoz, Spain, 2011.

55. Flores, C.L.; Garró, V.; Yrei, V.; Gallardo, T. Acción antimicrobiana Caesalpinea Tintoria (Molina) Kuntze o tara de diferentes regiones del Perú. Cienc. Investig. 1998, 1, 27-31. [CrossRef]

56. Jarma Orozco, A.; Cardona, A.C.; Araméndiz, T.H. Effect of climate change on the physiology of cultivated plants: A review. Rev. UDCA Act. Div. Cient. 2012, 15, 63-76.

57. Omoifo, C. Biochemical composition of soursop fruit, Annona muricata L., as affected by two harvest seasons. Trop. Agric. Res. Ext. 2004, 7, 1-8.

58. Ramírez, A.; Conejo-García, A.; Griñán-Lisón, C.; López-Cara, L.C.; Jiménez, G.; Campos, J.M.; Marchal, J.A.; Boulaiz, H. Enhancement of Tumor Cell Death by Combining gef Gene Mediated Therapy and New 1,4-Benzoxazepin-2,6-Dichloropurine Derivatives in Breast Cancer Cells. Front. Pharmacol. 2018, 9, 798. [CrossRef] [PubMed]

59. Arpa, T.L. Molecular Mechanisms that Regulate Classical and Alternative Activation in Macrophages. Ph.D. Thesis, Universitat de Barcelona, Barcelona, Spain, 2008.

60. Raynaud, S.; Némati, F.; Miccoli, L.; Michel, P.; Poupon, M.-F.; Fourneau, C.; Laurens, A.; Hocquemiller, R. Antitumoral effects of squamocin on parental and multidrug resistant MCF7 (human breast adenocarci-noma) cell lines. Life Sci. 1999, 65, 525-533. [CrossRef]

61. Choi, C.Y.; Kim, J.Y.; Kim, Y.S.; Chung, Y.C.; Seo, J.K.; Jeong, H.G. Aqueous extract isolated from Platycodon grandiflorum elicits the release of nitric oxide and tumor necrosis factor- $\alpha$ from murine macrophages. Int. Immunopharmacol. 2001, 1, 1141-1151. [CrossRef]

62. Yuan, S.-S.F.; Chang, H.-L.; Chen, H.-W.; Yeh, Y.-T.; Kao, Y.-H.; Lin, K.-H.; Wu, Y.-C.; Su, J.-H. Annonacin, a mono-tetrahydrofuran acetogenin, arrests cancer cells at the G1 phase and causes cytotoxicity in a Bax- and caspase-3-related pathway. Life Sci. 2003, 72, 2853-2861. [CrossRef]

63. AshaRani, P.; Low, K.M.G.; Hande, M.P.; Valiyaveettil, S. Cytotoxicity and genotoxicity of silver nano-particles in human cells. ACS Nano 2009, 3, 279-290. [CrossRef] 
64. Sonawane, A.; Jena, P.; Mohanty, S.; Mallick, R.; Jacob, B. Toxicity and antibacterial assessment of chitosan-coated silver nanoparticles on human pathogens and macrophage cells. Int. J. Nanomed. 2012, 7, 1805-1818. [CrossRef] [PubMed]

65. Moutin, M.-J.; Abramson, J.J.; Salama, G.; Dupont, Y. Rapid Ag+-induced release of Ca2+ from sarcoplasmic reticulum vesicles of skeletal muscle: A rapid filtration study. Biochim. Biophys. Acta Biomembr. 1989, 984, 289-292. [CrossRef]

66. Orrenius, S.; McCabe, M.J., Jr.; Nicotera, P. Ca2+-dependent mechanisms of cytotoxicity and programmed cell death. Toxicol. Lett. 1992, 64, 357-364. [CrossRef]

67. Sathishkumar, G.; Gobinath, C.; Wilson, A.; Sivaramakrishnan, S. Dendrophthoe falcata (L.f) Ettingsh (Neem mistletoe): A potent bioresource to fabricate silver nanoparticles for anticancer effect against human breast cancer cells (MCF-7). Spectrochim. Acta Part A Mol. Biomol. Spectrosc. 2014, 128, 285-290. [CrossRef] 